\title{
Relationship of phytohaemagglutinin- induced lymphocyte transformation to disease activity in systemic lupus erythematosus
}

\author{
P. HUGHES, SHIRLEY HOLT, N. R. ROWELL, AND JANIS K. DODD \\ From the University Departments of Pathology and Dermatology, General Infirmary at Leeds, and \\ University of Sheffield Academic Division of Medicine, Northern General Hospital, Sheffield
}

\begin{abstract}
Hughes, P., Holt, S., Rowell, N. R., and Dodd, J. K. (1976). Annals of the Rheumatic Diseases, 35, 97-105. Relationship of phytohaemagglutinin-induced lymphocyte transformation to disease activity in systemic lupus erythematosus. Phytohaemagglutinininduced lymphocyte transformation was studied in 19 patients with systemic lupus erythematosus (SLE) in relation to disease activity, peripheral blood lymphocyte count, serum iron and folate levels, and corticosteroid treatment. Similar studies were performed on a group of 28 age- and sex-matched controls and on 10 patients with facial palsy who were examined before and after 7 days of high-dose corticosteroid treatment.

The patients with SLE were found to have an impairment of lymphocyte transformation which was most marked in active stages of the disease and associated with a lymphopenia. This depressed transformation, which improved with the development of a remission, could not be attributed to the effects of corticosteroid treatment, inhibitory serum factors, iron deficiency, or any numerical reduction in blood lymphocytes, thus indicating along with evidence from other sources that SLE patients have a defect of cell-mediated immunity. The aetiological implications of these findings are discussed.
\end{abstract}

Systemic lupus erythematosus (SLE) is characterized by the presence of a wide range of autoantibodies (Holman, 1965). Little is known, however, of cellular immune function in this disorder despite the important co-operating and controlling effects that thymusdependent ( $T$ ) lymphocytes have on immune responses (Allison, Denman, and Barnes, 1971). Previous studies have produced evidence of cutaneous anergy both to tuberculin, streptokinase, candida, and mumps antigens (Toh and others, 1973) and to impaired mixed lymphocyte reactivity (Hedberg and others, 1971), suggesting that there may be a defect of cell-mediated immunity in SLE. The question of lymphocyte responsiveness to mitogens such as phytohaemagglutinin (PHA) has remained controversial with reports of both depressed (Bitter, Bitter, and Silberschmidt, 1971) and normal responses (Mellbye and others, 1973).

We have studied PHA-induced lymphocyte transformation in patients with SLE using the principle of the dose-response curve (Fitzgerald, 1971), con- sidering also disease activity and other possible modifying factors such as iron deficiency, variation in lymphocyte count, and corticosteroid therapy. The findings indicate that patients with SLE have impaired lymphocyte transformation responses to PHA and an associated lymphopenia, both being most marked in patients with active disease and both perhaps being implicated in the pathogenesis of the disorder.

\section{Materials and methods}

PATIENTS

Nineteen patients with SLE (Medical Research Council, $1961)$, one of whom was male, mean age $( \pm S D) 38 \cdot 2 \pm 15 \cdot 8$ years, were studied. Disease activity at the time of testing was assessed on the basis of the following criteria.

\section{Active disease}

Patients who were ill and usually in hospital with varying combinations of fever, serositis, nephritis, haemolysis, 
neurological manifestations, vasculitis, hypergammaglobulinaemia, anaemia, and an ESR $>50 \mathrm{~mm} / \mathrm{h}$. This group consisted of 5 women, mean age $( \pm S D) 23.6 \pm 5.9$ years.

\section{Slightly active disease}

Patients troubled by intermittent minor symptoms such as myalgia or arthralgia, but without evidence of active visceral disease, anaemia, or grossly raised ESR. This group consisted of 7 women, mean age $( \pm$ SD) $37 \cdot 5 \pm 9 \cdot 3$ years.

\section{Inactive disease}

Patients now well and free of symptoms with no anaemia or raised ESR. This group consisted of 7 patients, one male, mean age $( \pm S D) 49 \cdot 1 \pm 16 \cdot 1$ years.

Two patients with active disease were not receiving treatment with corticosteroids at the time of the initial tests. Prednisone dosage in the remainder is shown in Table II.

\section{CONTROLS}

Two groups of controls were used. (1) 27 healthy volunteers ( 2 males), mean age ( $\pm S D$ ) $37 \cdot 3 \pm 11 \cdot 4$ years. (2) In order to assess the effect of corticosteroids on lymphocyte transformation, 10 patients with facial palsy (7 males), mean age $( \pm S D) 38.4 \pm 10.3$ years, were studied before and after 7 days' treatment with prednisone $60 \mathrm{mg} /$ day.

Lymphocyte transformation was performed in both autologous plasma and human $A B$ serum by a modification of the whole blood micromethod of Junge and others (1970). For studies in autologous plasma, one part of whole blood, anticoagulated with preservative-free heparin (Boots Pure Drug Co., Nottingham) $20 \mathrm{U} / \mathrm{ml}$, was diluted with 9 parts TC199 (Wellcome Reagents Ltd., Beckenham), and aliquots $(1 \mathrm{ml})$ of this mixture were then cultured in triplicate in stoppered siliconized tubes at $37^{\circ} \mathrm{C}$ for 72 hours with PHA (MR 10, Wellcome Reagents Ltd., Beckenham) at 0,10 , and $50 \mu \mathrm{g} / \mathrm{ml}$. For studies in human AB serum, $2 \mathrm{ml}$ heparinized blood were washed three times with $10 \mathrm{ml}$ TC199 before finally being diluted 1 part in 9 with TC199 enriched with $5 \%$ human AB serum. Aliquots $(1 \mathrm{ml})$ were then similarly cultured and stimulated with PHA.

(3H) Methyl-thymidine, $2 \mu \mathrm{Ci}$ (specific activity 5 $\mathrm{Ci} / \mathrm{mmol}$ per 1, Radiochemical Centre, Amersham), was added to each tube for the last 4 hours of culture and, after a preliminary lysis of red blood cells by $3 \%$ acetic acid, DNA was then precipitated by $5 \%$ trichloracetic acid. The washed precipitate was solubilized with $1 \mathrm{~mol} / 1$ hyamine in methanol (Nuclear Enterprises Ltd., Edinburgh), incorporated into NE 220 scintillator fluid (Nuclear Enterprises Ltd., Edinburgh), and counted in a Packard Tri-Carb liquid scintillation counter. Results were expressed as the $\log _{10}$ of the average count per minute (cpm) of triplicate cultures.

\section{DESIGN OF INVESTIGATION}

The lymphocyte response to PHA, together with some of the factors capable of modifying it, was investigated as follows. (1) Transformation response in SLE patients was always tested in both autologous plasma and human AB serum. (2) Transformation response in the controls with facial palsy was also tested in both autologous plasma and human AB serum before and after 7 days' corticosteroid therapy. (3) Transformation response of normal controls was tested in autologous plasma only. (4) Inhibitory serum factors in SLE were also looked for by adding serum from 10 patients to replicate micromethod cultures from a single normal donor. The effect of the resulting $5 \%$ enrichment of the medium on the transformation response was observed. (5) The effect of variations in lymphocyte count on lymphocyte transformation was examined. The response in normal whole blood cultures, which had been diluted (1 in 19) to give lymphocyte counts comparable with those present in active SLE, was compared with that produced by the standard micromethod (diluted 1 in 9).

Absolute lymphocyte counts were calculated from total and differential leucocyte counts. Serum folate levels were estimated by the method of Millbank and others (1970). Serum iron levels were estimated by Autoanalyser. Lymphocytotoxins. Sera from 11 patients with SLE were examined for lymphocytotoxins (Ooi and others, 1974) using a panel of lymphocytes normally used for tissue typing.

\section{STATISTICAL METHODS}

As the variances of the lymphocyte transformation responses in some of the groups examined were not comparable by Student's ' $t$ ' test, the data were analysed by the Wilcoxon two-sample ranking test (Sokal and Rohlf, 1969). Comparison of absolute lymphocyte counts, serum iron and folate levels was made using Student's ' $t$ ' test.

\section{Results}

\section{LYMPHOCYTE TRANSFORMATION}

Lymphocyte transformation responses to $10 \mu \mathrm{g} / \mathrm{ml}$ and $50 \mu \mathrm{g} / \mathrm{ml}$ PHA in SLE patients and in the control groups are shown in Table I and Figs. 1-6. Normal controls responded in a uniform way (Table I) and the reproducibility of the method is illustrated by the serial observations made on one normal control (Fig. 5). Patients with SLE responded with more variation due to differences in the activity of their disease (Table I).

\section{Active SLE}

Lymphocyte transformation in these patients was markedly and significantly reduced at both concentrations of PHA in both human AB serum (PHA $10 \mu \mathrm{g} / \mathrm{ml}, \mathrm{t}=3.47, \mathrm{P}<0.01$; PHA $50 \mu \mathrm{g} / \mathrm{ml}, \mathrm{t}=2.51$, $\mathbf{P}<0.02$ ) and autologous plasma (PHA $10 \mu \mathrm{g} / \mathrm{ml}$, $\mathrm{t}=3.47, \mathrm{P}<0.01 ;$ PHA $50 \mu \mathrm{g} / \mathrm{ml}, \mathrm{t}=3.50, \mathrm{P}<0.01)$ when compared with the corresponding normal control values (Table I, Fig. 1). Although the response in human AB serum of this group appeared to be greater than in autologous plasma the difference was not significant $(P>0.1$ at PHA $10 \mu \mathrm{g} / \mathrm{ml}$ and $50 \mu \mathrm{g} / \mathrm{ml}$ ).

Serial observations made on one patient in this group are shown in Fig. 7. Lymphocyte transformation before corticosteroid treatment when the patient was ill with fever, haemolytic anaemia, pleurisy, and 
Table I Lymphocyte transformation responses and blood lymphocyte counts in patients with SLE and in controls

\begin{tabular}{|c|c|c|c|c|c|c|c|c|c|}
\hline \multirow[t]{3}{*}{ Group studied } & \multirow[t]{3}{*}{ No. } & \multirow[t]{3}{*}{$\begin{array}{l}\text { Age }(\text { years }) \\
(\text { mean } \pm S D)\end{array}$} & \multirow{3}{*}{$\begin{array}{l}\text { Blood } \\
\text { lymphocytes } \\
\left(\times 10^{9} \mid l\right) \ddagger \\
(\text { mean } \pm S D)\end{array}$} & \multicolumn{6}{|c|}{$\begin{array}{l}\text { Lymphocyte transformation responses }\left(\log _{10} c p m\right) \\
(\text { mean } \pm S D)\end{array}$} \\
\hline & & & & \multicolumn{3}{|c|}{$\begin{array}{l}\text { Autologous plasma PHA } \\
\text { concentration }(\mu \mathrm{g} / \mathrm{ml})\end{array}$} & \multicolumn{3}{|c|}{$\begin{array}{l}\text { Human } A B \text { serum } P H A \\
\text { concentration }(\mu g / m l)\end{array}$} \\
\hline & & & & 0 & 10 & 50 & 0 & 10 & 50 \\
\hline $\begin{array}{l}\text { SLE }^{*} \\
\text { Active }\end{array}$ & 5 & $23 \cdot 6 \pm 5 \cdot 9$ & $1.3 \pm 0.33$ & $\begin{array}{r}2.5013 \\
\pm 0.2283\end{array}$ & $\begin{array}{r}2 \cdot 8908 \\
\pm 0.5496\end{array}$ & $\begin{array}{r}3 \cdot 6924 \\
\pm 0.3992\end{array}$ & $\begin{array}{r}2 \cdot 6131 \\
\pm 0.3217\end{array}$ & $\begin{array}{r}3 \cdot 4392 \\
\pm 0.4083\end{array}$ & $\begin{array}{r}3 \cdot 8594 \\
\pm 0 \cdot 6410 \\
\end{array}$ \\
\hline Slightly active & 7 & $37 \cdot 5 \pm 9 \cdot 3$ & $1 \cdot 7 \pm 0 \cdot 77$ & $\begin{array}{r}2.3094 \\
\pm 0.2056\end{array}$ & $\begin{array}{r}3.9151 \\
\pm 0.5432\end{array}$ & $\begin{array}{r}4 \cdot 3253 \\
\pm 0.4104\end{array}$ & $\begin{array}{r}2 \cdot 2831 \\
\pm 0 \cdot 2264\end{array}$ & $\begin{array}{r}3.9034 \\
\pm 0.2973\end{array}$ & $\begin{array}{r}4 \cdot 1878 \\
\pm 0 \cdot 3253\end{array}$ \\
\hline Inactive & 7 & $\overline{49 \cdot 1 \pm 16 \cdot 1}$ & $2 \cdot 4 \pm 1 \cdot 09$ & $\begin{array}{r}2 \cdot 2121 \\
\pm 0 \cdot 2109\end{array}$ & $\begin{array}{r}4 \cdot 1842 \\
+0 \cdot 1491\end{array}$ & $\begin{array}{r}4.4475 \\
\pm 0.3146\end{array}$ & $\begin{array}{r}1.9332 \\
\pm 0.2578\end{array}$ & $\begin{array}{r}4 \cdot 1082 \\
\pm 0 \cdot 1756\end{array}$ & $\begin{array}{r}4 \cdot 5265 \\
\pm 0 \cdot 0960\end{array}$ \\
\hline Normal controls & 28 & $37 \cdot 3 \pm 11 \cdot 4$ & $2.3 \pm 0.59$ & $\begin{array}{r}2 \cdot 3262 \\
\pm 0 \cdot 1737\end{array}$ & $\begin{array}{r}4.5747 \\
\pm 0.2293\end{array}$ & $\begin{array}{r}4 \cdot 6897 \\
\pm 0 \cdot 2139\end{array}$ & - & - & - \\
\hline $\begin{array}{l}\text { Normal controls (with } \\
\text { halved lymphocyte } \\
\text { count) } \dagger\end{array}$ & 7 & $38 \cdot 6 \pm 13 \cdot 3$ & $1 \cdot 3 \pm 0.34$ & $\begin{array}{r}2.1789 \\
\pm 0.1626\end{array}$ & $\begin{array}{r}4.4143 \\
\pm 0.3173\end{array}$ & $\begin{array}{r}4.8336 \\
\pm 0.1827\end{array}$ & - & - & - \\
\hline $\begin{array}{l}\text { One normal control } \\
\text { Replicate cultures }\end{array}$ & 5 & 45 & $2.5 \pm 0.68$ & $\begin{array}{r}2.3536 \\
\pm 0.0879\end{array}$ & $\begin{array}{r}4 \cdot 6612 \\
\pm 0 \cdot 1644\end{array}$ & $\begin{array}{r}4.6653 \\
\pm 0.2983\end{array}$ & - & - & - \\
\hline $\begin{array}{l}\text { Replicate cultures } \\
\text { enriched with } \\
5 \% \text { SLE serum }\end{array}$ & 10 & 45 & $2 \cdot 5 \pm 0 \cdot 68$ & $\begin{array}{r}2 \cdot 3067 \\
\pm 0.1746\end{array}$ & $\begin{array}{r}4 \cdot 1341 \\
\pm 0.4287\end{array}$ & $\begin{array}{r}4 \cdot 5546 \\
\pm 0 \cdot 2322\end{array}$ & - & - & - \\
\hline $\begin{array}{l}\text { Facial palsy } \\
\text { Presteroid treatment }\end{array}$ & 10 & $38 \cdot 4 \pm 10 \cdot 3$ & $2 \cdot 0 \pm 0.48$ & $\begin{array}{r}2.2488 \\
\pm 0.1402\end{array}$ & $\begin{array}{r}4.3625 \\
\pm 0.2454\end{array}$ & $\begin{array}{r}4.6738 \\
\pm 0.2839\end{array}$ & $\begin{array}{r}2.2378 \\
\pm 0.1226\end{array}$ & $\begin{array}{r}4.3681 \\
\pm 0.2009\end{array}$ & $\begin{array}{r}4.6325 \\
\pm 0.1203\end{array}$ \\
\hline Poststeroid treatment & $\overline{10}$ & $\overline{38 \cdot 4 \pm 10 \cdot 3}$ & $\overline{2.9 \pm 0.91}$ & $\begin{array}{r}2 \cdot 5014 \\
\pm 0 \cdot 2884\end{array}$ & $\begin{array}{r}4.2089 \\
\pm 0.2595\end{array}$ & $\begin{array}{r}4.5737 \\
\pm 0.2846\end{array}$ & $\begin{array}{r}2.5222 \\
\pm 0.2076\end{array}$ & $\begin{array}{r}4 \cdot 2441 \\
\pm 0 \cdot 3844\end{array}$ & $\begin{array}{r}4.5965 \\
\pm 0.2269\end{array}$ \\
\hline
\end{tabular}

* Grades of activity as defined in text.

+ See Methods.

$\ddagger$ Conversion: SI to Traditional Units-Lymphocytes: $4 \cdot 0 \times 10^{9} / 1 \simeq 4000 / \mathrm{mm}^{3}$.

Raynaud's phenomenon, was grossly depressed but then rose towards normal as the disease went into a clinical and serological remission over 9 months with prednisone therapy.

\section{Slightly active SLE}

Although not as depressed as in active SLE, lymphocyte transformation in these patients was once more significantly impaired at both concentrations of PHA in both human AB serum (PHA $10 \mu \mathrm{g} / \mathrm{ml}, \mathrm{t}=3.68$, $\mathrm{P}<0.001$; PHA $50 \mu \mathrm{g} / \mathrm{ml}, \mathrm{t}=3.33, \mathrm{P}<0.001)$ and autologous plasma (PHA $10 \mu \mathrm{g} / \mathrm{ml}, \mathrm{t}=2 \cdot 85, \mathrm{P}<$ 0.01 ; PHA $50 \mu \mathrm{g} / \mathrm{ml}, \mathrm{t}=2.03, \mathrm{P}<0.02$ ) when compared with the response of normal controls (Table I, Fig. 2).

\section{Inactive SLE}

Lymphocyte transformation in these patients was much nearer to the normal range than in either of the two groups above. Nevertheless, when compared with normal controls, the responses were still significantly impaired at $10 \mu \mathrm{g} / \mathrm{ml}$ PHA in both autologous plasma $(\mathrm{t}=3.43, \mathrm{P}<0.01)$ and human $A B \operatorname{serum}(\mathrm{t}=3.09, \mathrm{P}<0.01)$ and at $50 \mu \mathrm{g} / \mathrm{ml}$ PHA in autologous plasma $(t=2.32, P<0.05)$. The response at $50 \mu \mathrm{g} / \mathrm{ml}$ PHA in human $A B$ serum, however, was not significant $(t=1.88, P>0.05)$ (Table I, Fig. 3).

\section{Facial palsy group}

Lymphocyte transformation in these patients, before steroid treatment, was slightly but significantly impaired at $10 \mu \mathrm{g} / \mathrm{ml}$ PHA $(\mathrm{t}=2.31, \mathrm{P}<0.05)$ but did not differ from the normal control response at $50 \mu \mathrm{g} / \mathrm{ml}$ PHA $(\mathrm{t}=0 \cdot 12, \mathrm{P}>0 \cdot 1)$. Treatment with prednisone $(60 \mathrm{mg} / \mathrm{d}$ for 7 days) resulted in a reduction of the response at both concentrations of PHA in both human $\mathrm{AB}$ serum and autologous plasma but 


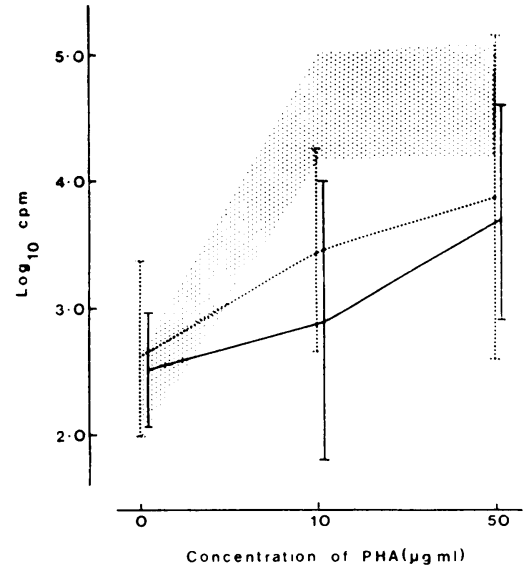

FIG. 1 Phytohaemagglutinin (PHA)-induced lymphocyte transformation in SLE. Dose-response curves (mean \pm 2 $S D)$ in autologous plasma (-) and human $A B$ serum $(\cdots \cdots)$ in 5 patients with active SLE compared with the response of 28 normal controls in autologous plasma (hatching)

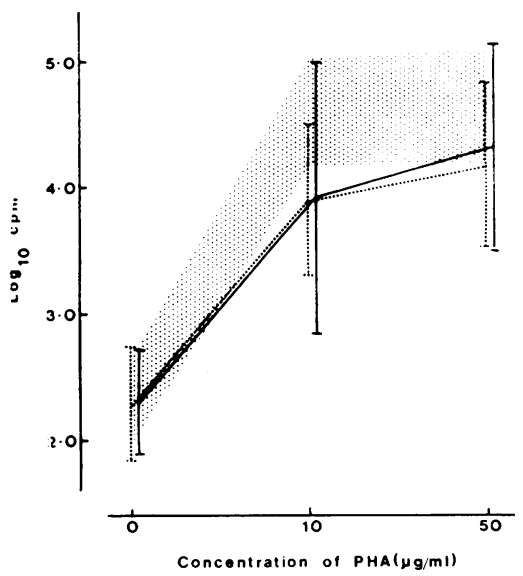

FIG. $2 P H A$-induced lymphocyte transformation in SLE. Dose-response curves (mean $\pm 2 S D$ ) in autologous plasma $(\longrightarrow)$ and human $A B$ serum $(\cdots)$ in 7 patients with slightly active SLE compared with the response of 28 normal controls in autologous plasma (hatching)

this degree of impairment was not, surprisingly, significant $(\mathrm{P}>0 \cdot 1$ at PHA $10 \mu \mathrm{g} / \mathrm{ml}$ and $50 \mu \mathrm{g} / \mathrm{ml})$ (Table I, Fig. 4).

Inhibitory serum factors

Enrichment of a series of replicate lymphocyte cultures from one normal control with serum from 10 SLE patients (3 of whom had active disease) failed to produce a significant reduction in the transformation of the normal lymphocytes at $50 \mu \mathrm{g} / \mathrm{ml} \mathrm{PHA}$, either when compared against the replicate responses of the original donor $(\mathrm{P}>\mathbf{0} \cdot 1)$ or against the response of the whole normal control group $(t=1 \cdot 46, P>0 \cdot 1)$. There was, however, $a$ significant reduction in the transformation response of normal lymphocytes at $10 \mu \mathrm{g} / \mathrm{ml}$ PHA when compared with the whole of the normal control group $(\mathrm{t}=3.22, \mathrm{P}<0.01$ ) (Table I, Fig. 5), but which was not significant when compared with the replicate responses of the original donor $(P>0 \cdot 1)$. This isolated instance of an apparent impairment of the transformation response of normal lymphocytes by

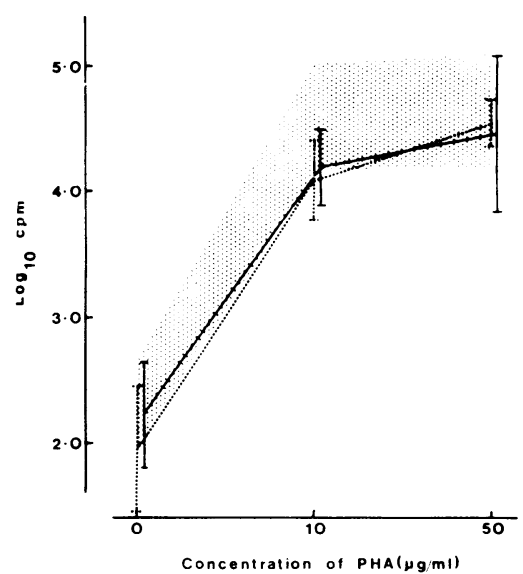

FIG. 3 PHA-induced lymphocyte transformation in SLE. Dose-response curves (mean $\pm 2 S D$ ) in autologous plasma $(-)$ and human $A B$ serum $(\cdots)$ in 7 patients with inactive SLE compared with the response of 28 normal controls in autologous plasma (hatching)

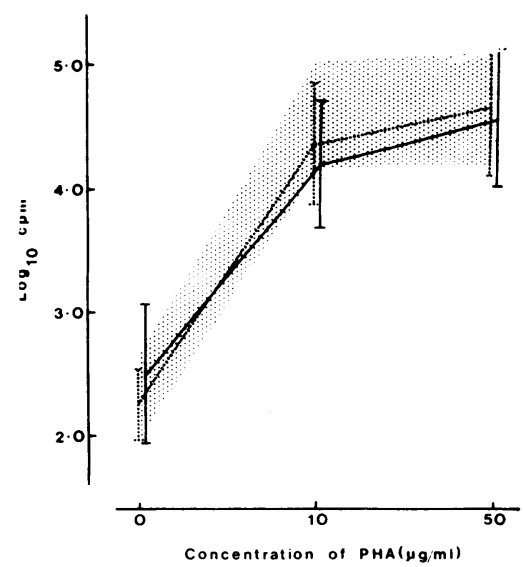

FIG. 4 PHA-induced lymphocyte transformation in 10 patients with facial palsy. Dose-response curves (mean \pm $2 S D)$ in autologous plasma before $(\cdots)$ ) and after (-) 7 days' treatment with prednisone $60 \mathrm{mg} /$ day, compared with the response of 28 normal controls in autologous plasma (hatching) 


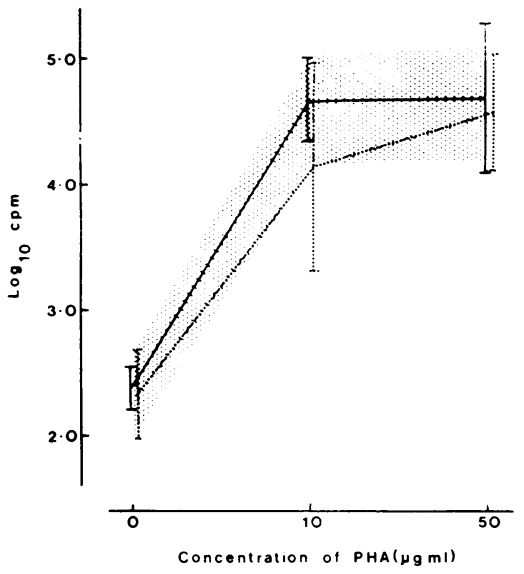

FIG. 5 Modification of PHA-induced lymphocyte transformation by SLE serum. Dose-response curves (mean \pm $2 S D$ ) in autologous plasma of 5 replicate cultures of one normal control (-) compared with (a) 10 similar cultures enriched with $5 \%$ serum from patients with SLE $(\cdots)$ ), and (b) 28 normal controls (hatching)

serum from patients with SLE does not provide sufficient evidence that the impaired response of patients, particularly those with active disease, was due to the operation of inhibitory serum factors. Individual results, in fact, showed that any depression of transformation was usually only produced by sera from patients whose own responses were not markedly impaired, whereas the sera of patients with gross impairment of transformation had little or no effect on the response of normal lymphocytes. This situation is best exemplified by one patient (Fig. 7) whose lymphocyte transformation response was grossly impaired at a time when her serum had no effect whatsoever on the transformation response of normal lymphocytes in spite of the presence of lymphocytotoxins.

\section{Variation in lymphocyte count}

A reduction of lymphocytes to the numbers found in patients with active SLE had no significant effect $(t=1 \cdot 62, P>0 \cdot 1)$ on the transformation response of normal lymphocytes (Table I, Fig. 6).

\section{ABSOLUTE LYMPHOCYTE COUNTS}

The results of the mean absolute lymphocyte counts for patients with SLE and the control groups are shown in Table II. The patients with active SLE had a significant lymphopenia when compared with normal controls $(t=3.79, P<0.001)$ and although the lymphopenia was less marked in patients with only slight disease activity, the reduction was nevertheless significant $(t=2.12, P<0.02)$. The mean lymphocyte count of patients with inactive SLE did not, however, differ significantly from that of the normal controls $(t=0 \cdot 21, P>0 \cdot 1)$.

\section{SERUM IRON AND FOLATE LEVELS}

The mean serum iron and folate levels for patients with SLE and the control groups are shown in Table II. Serum iron levels were significantly lower in patients with SLE than in controls $(t=4 \cdot 39$, $P<0.001$ ) but did not differ significantly when the various subgroups of SLE were compared with each other. There was no significant difference in serum folate levels in any of the groups studied.

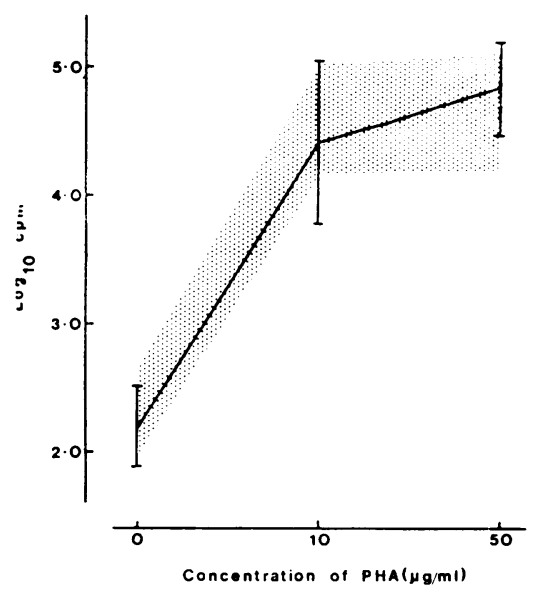

FIG. 6 PHA-induced lymphocyte transformation in normal controls. Comparison of dose-response curves (mean $\pm 2 S D$ ) in autologous plasma of 28 normal controls (hatching) with cultures from 7 normal controls $(-)$ diluted to give lymphocyte counts comparable with those present in patients with active SLE

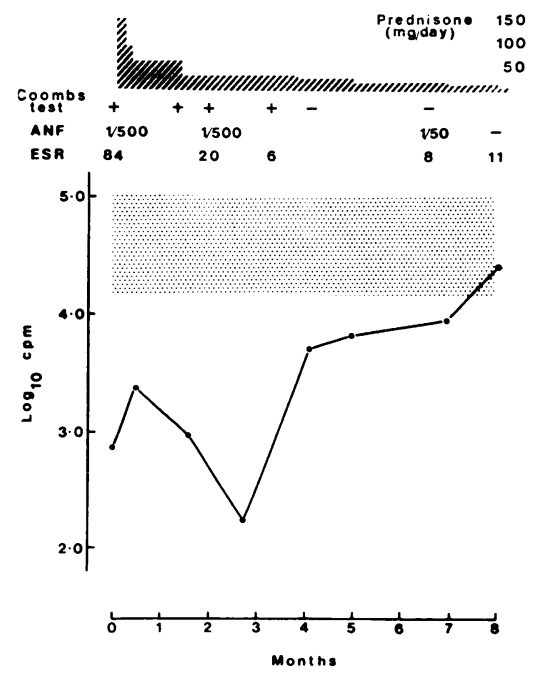

FIG. 7 PHA-induced lymphocyte transformation in SLE; serial studies (PHA $10 \mu \mathrm{g} / \mathrm{ml}$ ) in one patient (-) during transition from untreated active disease to a clinical and serological remission, compared with the corresponding responses (mean $\pm 2 S D$ ) of 28 normal controls (hatching) 
Table II Serum iron and folate levels and corticosteroid dosage in patients with SLE and controls

\begin{tabular}{|c|c|c|c|}
\hline Group studied & $\begin{array}{l}\text { Serum iron }(\mu g / m l) \\
(\text { mean } \pm S D)\end{array}$ & $\begin{array}{l}\text { Serum folate }(\mu g / m l) \\
(\text { mean } \pm S D)\end{array}$ & $\begin{array}{l}\text { Prednisone (mg/day } \\
(\text { mean } \pm S D)\end{array}$ \\
\hline $\begin{array}{l}\text { SLE* } \\
\text { Total group }\end{array}$ & $79 \cdot 0 \pm 23 \cdot 5$ & $7 \cdot 5 \pm 4 \cdot 9$ & $9 \cdot 5 \pm 6 \cdot 6$ \\
\hline Active & $77 \cdot 6 \pm 24 \cdot 0$ & $9 \cdot 6 \pm 8 \cdot 1$ & $20 \dagger$ \\
\hline Slightly active & $82 \cdot 1 \pm 27 \cdot 3$ & $6 \cdot 0 \pm 1 \cdot 0$ & $8 \cdot 9 \pm 5 \cdot 0$ \\
\hline Inactive & $76 \cdot 8 \pm 22 \cdot 6$ & $7 \cdot 1 \pm 3 \cdot 8$ & $8 \cdot 2 \pm 3 \cdot 7$ \\
\hline Normal control & $112 \cdot 8 \pm 48.9$ & $8 \cdot 5 \pm 3 \cdot 2$ & 0 \\
\hline $\begin{array}{l}\text { Facial palsy } \\
\text { Presteroid treatment }\end{array}$ & $107 \cdot 7 \pm 31 \cdot 2$ & $9 \cdot 4 \pm 3 \cdot 1$ & 0 \\
\hline Post-steroid treatment & - & - & 60 \\
\hline
\end{tabular}

* Grades of activity as defined in text.

† Two patients were untreated at the initial tests; the remaining 3 patients each received $20 \mathrm{mg}$ prednisone/day.

\section{LYMPHOCYTOTOXINS}

Lymphocytotoxins, which were optimally active at $15^{\circ} \mathrm{C}$, were detected in 4 of the 11 sera examined. A strong reaction was, however, found with only one serum (patient in Fig. 7) while the remaining 3 sera showed only weak lymphocytotoxic activity.

\section{Discussion}

This investigation has shown that patients with SLE have an impaired lymphocyte transformation response to PHA. This impairment was most obvious when suboptimal stimulatory doses of PHA were used and was marked in those patients with active disease. Although much less impairment was seen in patients whose disease was relatively quiescent, transformation responses were still significantly depressed even in patients in complete remission. These findings confirm and extend earlier published reports (Bitter and others, 1971; Rosenthal and Franklin, 1973; Paty and others, 1974) and together with the cutaneous anergy noted (Block and others, 1968; Toh and others, 1973), suggest that patients with SLE have an impairment of at least some aspects of cell-mediated immune function. The association of depressed transformation responses with both lymphopenia and disease activity is a particularly interesting aspect of this investigation as is the serial improvement in the PHA-responsiveness noted in one of the patients during a clinical and serological remission (Fig. 7).

Several factors could be involved in the depressed lymphocyte transformation observed. Firstly, the inhibitory effect of corticosteroids (Elves, Gough, and Israels, 1964; Heilman, Gambrill, and Leichner, 1973) should be considered as so many of the patients under investigation were receiving treatment with these drugs. It is unlikely, however, that the major part of the impaired lymphocyte responsiveness seen in patients with active disease can be attributed to such therapy. Corticosteroid treatment of the control group with facial palsy never produced as profound a depression of lymphocyte transformation as that seen in active SLE. Moreover, patients with clinically quiescent SLE had higher lymphocyte transformation responses than those with more active disease despite receiving a similar mean dose of prednisone (Table II). Further evidence was provided by the 2 patients with active disease both of whom had depressed lymphocyte transformation before treatment, serial studies showing an increasing transformation response in one as the disease went into remission during corticosteroid therapy (Fig. 7). A similar impairment of lymphocyte transformation in untreated active disease (Bitter and others, 1971) with improvement in response during onset of a remission (Rosenthal and Franklin, 1973) was also noted in two earlier studies.

Secondly, the effect of inhibitory serum factors (Cooperband and others, 1968; Milton, 1971) should also be considered, particularly as lymphocytotoxins (Terasaki, Mottironi, and Barnett, 1970; Statsny and Ziff, 1971) with relative T-lymphocyte specificity (Lies, Messner, and Williams, 1973) have been found with a high frequency in the serum in SLE. The experiments which involved the addition of patients' serum to control cultures and the parallel use of human AB serum cultures all failed, however, to show the presence of any inhibitory serum factors which could account for the markedly depressed lymphocyte responses found in active disease. Moreover, lymphocytotoxins are optimally active at $15-22^{\circ} \mathrm{C}$ and have little or no activity at the temperatures present either in the whole blood cultures or 
in vivo (Terasaki and others, 1970; Ooi and others, 1974). This point is illustrated by the serum of the patient in Fig. 7, which contained lymphocytotoxins but which failed to impair the transformation response of normal lymphocytes.

Another important factor is iron status as there is evidence that lymphocyte responsiveness is depressed by iron deficiency (Joynson and others, 1972). Although the mean serum iron level in all the patients with SLE was significantly lower than in any of the control groups, the patients with active disease and the most depressed lymphocyte transformation had mean serum iron levels that did not differ significantly from those found in patients in remission with much higher responses. We do not think, therefore, that iron deficiency can account for our findings.

The final possibility is that the impaired lymphocyte responsiveness to PHA present in SLE may be due to a quantitative and/or qualitative defect in the lymphocytes. A striking feature of this investigation has been that both disease activity and depressed lymphocyte transformation in SLE have been paralleled by a reduction in the peripheral blood lymphocyte count. Although a reduction of normal blood lymphocytes to the numbers present in active SLE did not produce any impairment of the lymphocyte transformation response, there is evidence that lymphocyte subpopulations in SLE are no longer normal. Messner, Lindström, and Williams (1973) reported a deficiency of T-lymphocytes in the disorder, and such a deficiency could, therefore, underlie the depressed transformation responses noted by us.

However, the gross impairment of transformation seen in some patients with active disease, amounting at times to almost complete unresponsiveness (Fig. 7), suggests that there is also likely to be some qualitative defect in the lymphocytes in these cases. Such immunodepression might be purely a secondary effect, analogous to the general depression of cellmediated immunity that can result from the antigenic competition of graft versus host disease (Lapp and Möller, 1969; Möller, 1971). Alternatively, it may indicate some derangement of immunological mechanisms such as the loss of T-lymphocyte suppressor function that has been postulated to underlie autoimmune reactions (Allison, 1973). If either were the case then a similar reduction in lymphocyte responsiveness to mitogens might be expected in other situations involving autoimmunity. Evidence is still incomplete, but impaired lymphocyte transformation has been reported in Sjøgren's syndrome, rheumatoid arthritis, and chronic active hepatitis (Leventhal, Waldorf and Talal, 1967; Toh and others, 1973), while a rising incidence of autoantibodies (Hill, 1961; Beck, 1963) and decreasing lymphocyte responsiveness to mitogens (Roberts-Thomson and others, 1974) are both associated with increasing age.
Finally, both depressed lymphocyte transformation (Salaman, 1970) and a reduction in circulating T-lymphocytes (Wybran and Fudenberg, 1973) have been recorded as transient features of certain virus infections, and the similarity of these observations to the findings of the present study are striking. Although doubt has been expressed about the true virus nature of the virus-like particles present in the lymphocytes and endothelial cells in SLE (Pincus and others, 1970), there is some evidence for a link with virus infection in the disorder. Patients with SLE have an increased incidence of high titre antibodies to several viruses (Evans, Rothfield, and Niederman, 1971; Hollinger and others, 1971; Hurd and others, 1972; Phillips and Christian, 1973; Laitinen and Vaheri, 1974) some of which are known to produce a temporary depression of cell-mediated immunity during infection (Starr and Berkovich, 1964; Rubin, 1966; Olson and others, 1968; Sheldon and others, 1973). In addition, the antibodies against RNA that are also frequently present in SLE are directed against the double-stranded form which is only found in large amounts in mammalian tissue if it is infected by an RNA virus (Schur and others, 1971). In experimental animals the lupus-like autoimmune disease of the NZB mouse is known to be associated with persisting infection with murine leukaemia virus (Levy and Pincus, 1970; Mellors and others, 1971) and as these animals age and develop autoimmune manifestations the T-lymphocytes show signs of deteriorating function, including impairment of the transformation response to PHA (Rodey, Good, and Yunis, 1971). These results and the recent report of an apparently selective impairment of cell-mediated immunity to measles virus in SLE (Utermohlen and others, 1974), coupled with increasing evidence to support a general cellular immune defect especially in active stages of SLE, should stimulate further investigation into the part played by virus infections in the pathogenesis of the disease.

We thank the following members of the staff of the General Infirmary at Leeds: Dr. B. E. Roberts, Department of Haematology, for blood counts and serum folate estimations; Professor G. Lathe, Department of Chemical Pathology, for serum iron estimations; Dr. C. J. Hayter, Department of Nuclear Medicine, for facilities for radioactive work; Professor G. Gowland, Department of Immunology, for liquid scintillation counting facilities; and Dr. D. Taverner for access to patients under his care.

We also thank Dr. W. Wagstaff and Mr. K. Gelsthorpe of the Sheffield Regional Blood Transfusion Centre, for the detection of lymphocytotoxins; and Mr. R. A. Forster, Department of Dermatology, for continuous expert technical assistance. Finally, we are very grateful to all those, both patients and controls, who so willingly gave blood for this investigation. 


\section{References}

Aluison, A. C. (1973) Ann. rheum. Dis., 32, 283 (Mechanisms of tolerance and auto-immunity)

- - Demman, A. M., AND Barnes, R. D. (1971) Lancet, 2, 135 (Cooperating and controlling functions of thymusdependent lymphocytes in relation to auto-immunity)

BECK, J. S. (1963) Scot. med. J., 8, 373 (Auto-antibodies to cell nuclei)

BitTer, T., Bitter, F., AND Silberschmidt, R. (1971) Arthr. and Rheum., 14, 152 (In vivo and in vitro study of cell-mediated immunity during the onset of systemic lupus erythematosus)

Block, S. R., Gibbs, C. B., Stevens, M. B., And Shulman, L. E. (1968) Ann. rheum. Dis., 27, 311 (Delayed hypersensitivity in systemic lupus erythematosus)

Cooperband, S. R., Bondevik, H., Schmid, K., And Mannik, J. A. (1968) Science, N. Y., 159, 1243 (Transformation of human lymphocytes: inhibition by homologous alpha-globulin)

Elves, M. W., Gough, J., AND IsRaels, M. C. G. (1964) Acta haemat., 32, 100 (Place of lymphocytes in reticuloendothelial system: study of in vitro effect of prednisone on lymphocytes)

Evans, A. S., Rothfield, M. F., And Niederman, J. C. (1971) Lancet, 1, 167 (Raised antibody titres to E.B. virus in systemic lupus erythematosus)

FitzGerald, M. G. (1971) Clin. exp. Immunol., 8, 421 (The establishment of a normal human population doseresponse curve for lymphocytes cultured with PHA (phytohaemagglutinin))

Hedberg, H., Källén, B., Löw, B., AND Nilsson, O. (1971) Ibid., 9, 201 (Impaired mixed leucocyte reaction in some different diseases, notably multiple sclerosis and various arthritides)

Heilman, D. H., Gambrill, M. R., And Leichner, J. P. (1973) Ibid., 15, 203 (The effect of hydrocortisone on the incorporation of tritiated thymidine by human blood lymphocytes cultured with phytohaemagglutinin and pokeweed mitogen)

HILl, O. W. (1961) Brit. med. J., 1, 1793 (Thyroglobulin antibodies in 1,297 patients without thyroid disease)

Hollinger, F. B., Sharp, J. T., Lidsky, M. D., and Rawls, W. E. (1971) Arthr. and Rheum., 14, 1 (Antibodies to viral antigens in systemic lupus erythematosus)

Holman, H. R. (1965) 'Systemic lupus erythematosus', in 'Immunological Diseases', ed. M. Samter, p. 737. Churchill, London

Hurd, E. R., Dowdle, W., Casey, H., ANd Ziff, M. (1972) Arthr. and Rheum., 15, 267 (Virus antibody levels in systemic lupus erythematosus)

Joynson, D. H. M., Jacobs, A., Murray Walker, D., AND Dolby, A. E. (1972) Lancet, 2, 1058 (Defect of cellmediated immunity in patients with iron-deficiency anaemia)

Junge, U., Hoekstra, J., Wolfe, L., AND Deinhardt, F. (1970) Clin. exp. Immunol., 7, 431 (Microtechnique for quantitative evaluation of in vitro lymphocyte transformation)

LaItinen, O., AND VAHERI, A. (1974) Lancet, 1, 194 (Very high measles and rubella virus antibody titres associated with hepatitis, systemic lupus erythematosus and infectious mononucleosis)

LAPP, W. S., AND MölleR, G. (1969) Immunology, 17, 339 (Prolonged survival of H-2 incompatible skin allografts on $\mathrm{F}_{1}$ animals treated with parental lymphoid cells)

LeVenthal, B. G., Waldorf, D. S., AND Talal, N. (1967) J. clin. Invest., 46, 1338 (Impaired lymphocyte transformation and delayed hypersensitivity in Sjögren's syndrome)

Levy, J. A., AND Pincus, T. (1970) Science, 170, 326 (Demonstration of biological activity of a murine leukaemia virus of New Zealand black mice)

Lies, R. B., Messner, R. P., AND Williams, R. C. (1973) Arthr. and Rheum., 16, 369 (Relative T-cell specificity of lymphocytotoxins from patients with systemic lupus erythematosus)

Medical ReSeARCH CounCil (1961) Brit. med. J., 2, 915 (Treatment of systemic lupus erythematosus with steroids. Report to Medical Research Council by the Collagen Diseases and Hypersensitivity Panel)

Mellbye, O. J., Lindström, F. D., Eberle, B. J., and Williams, R. C. (1973) Clin. exp. Immunol., 15, 157 (Reactivity of RA and SLE lymphocytes stimulated by anti-Ig antibodies)

Mellors, R. C., Shirai, T., Aoki, T., Huebner, R. J., AND KrawCZynski, K. (1971) J. exp. Med., 133, 113 (Wild-type gross leukaemia virus and the pathogenesis of the glomerulonephritis of New Zealand mice)

Messner, R. P., Lindström, F. D., AND Williams, R. C. (1973) J. clin. Invest., 52, 3046 (Peripheral blood lymphocyte cell surface markers during the course of systemic lupus erythematosus)

Millbank, L., Davis, R. E., Rawlins, M., and Waters, A. H. (1970) J. clin. Path., 23, 54 (Automation of the assay of folate in serum and whole blood)

Milton, J. D. (1971) Immunology, 20, 205 (Effect of an immunosuppressive serum glyco-protein with ribo-nuclease activity on the proliferation of human lymphocytes in culture)

MölLER, G. (1971) Ibid., 20, 597 (Suppressive effect of graft versus host reaction on the immune response to heterologous red cells)

Olson, G. B., Dent, P. B., Rawls, W. E., South, M. A., Montgomery, J. R., Melnick, J. L., And Good, R. A. (1968) J. exp. Med., 128, 47 (Abnormalities of in vitro lymphocyte responses during rubella virus infections)

Ooi, B. S., Orlina, A. R., Pesce, A. J., Mendoza, N., Masaitis, L., and Pollak, V. E. (1974) Clin. exp. Immunol., 17, 237 (Lymphocytotoxic antibodies in patients with systemic lupus erythematosus)

Paty, J. G., Sienknecht, C. W., Townes, A. S., Hanissian, A. S., and Masi, A. I. (1974) Arthr. and Rheum., 17, 324 (Impaired cell-mediated immunity in systemic lupus erythematosus and rheumatoid arthritis) 
Phillips, P. E., ANd Christian, C. L. (1973) Ann. rheum. Dis., 32, 450 (Virus antibodies in systemic lupus erythematosus and other connective tissue diseases)

Pincus, T., Blacklow, N. R., Grimley, P. M., and Bellanti, J. A. (1970) Lancet, 2, 1058 (Glomerular microtubules of systemic lupus erythematosus)

Roberts-Thomson, I. C., WhitTingham, S., YoungchaiYud, U., AND MACKaY, I. R. (1974) Ibid., 2, 368 (Ageing, immune response, and mortality)

Rodey, G. E., Good, R. W., AND Yunis, G. J. (1971) Clin. exp. Immunol., 9, 305 (Progressive loss in vitro of cellular immunity with ageing in strains of mice susceptible to autoimmune disease)

Rosenthal, C. J., AND Franklin, E. C. (1973) Arthr. and Rheum., 16, 565 (Deficiency of cell mediated immunity (CMI) in active SLE: changing patterns after steroid therapy)

RubiN, A. D. (1966) Blood, 28, 602 (Lymphocyte RNA synthesis in infectious mononucleosis: the response to phytohaemagglutinin in vitro)

Salaman, M. H. (1970) Proc. roy. Soc. Med., 63, 11 (Immunodepression by mammalian viruses and plasmodia)

Schur, P. H., Stollar, B. D., Steinberg, A. D., and Talal, N. (1971) Arthr. and Rheum., 14, 342 (Incidence of antibodies to double-stranded RNA in systemic lupus erythematosus and related diseases)

Sheldon, P. J., Hemsted, E. H., Papamichail, M., AND Holborow, E. J. (1973) Lancet, 1, 1153 (Thymic origin of atypical lymphoid cells in infectious mononucleosis)

SoKal, R. R., AND ROHLF, F. J. (1969) 'Biometry. The principle and practice of statistics in biological research', p. 391. Freeman, San Francisco

StarR, S., AND Berkovich, S. (1964) New Engl. J. Med., 270, 386 (Effect of measles, gamma-globulin-modified measles and vaccine measles on the tuberculin test)

StatSNy, P., AND ZIFF, M. (1971) Clin. exp. Immunol., 8, 543 (Antibodies against cell membrane constituents in systemic lupus erythematosus and related diseases. I. Cytotoxic effect of serum from patients with systemic lupus erythematosus (SLE) for allogenic and for autologous lymphocytes)

Terasaki, P. I., Mottironi, U. D., AND BARNeTt, E. V. (1970) New Engl. J. Med., 283, 724 (Cytotoxins in disease. Autocytotoxins in lupus)

Toh, B. H., Roberts-Thomson, I. C., Mathews, J. D., Whittingham, S., and Mackay, I. R. (1973) Clin. exp. Immunol., 14, 193 (Depression of cell-mediated immunity in old age and the immunopathic diseases, lupus erythematosus, chronic hepatitis and rheumatoid arthritis)

Utermohlen, V., Winfield, J. B., Zabriskie, J. B., AND Kunel, H. G. (1974) J. exp. Med., 139, 1019 (A depression of cell-mediated immunity of measles antigens in patients with systemic lupus erythematosus)

WyBRAN, J., AND FuDENBERG, H. H. (1973) J. clin. Invest., 52, 1026 (Thymus-derived rosette-forming cells in various human disease states: cancer, lymphoma, bacterial and viral infections, and other diseases) 